\title{
Kosovo-Serbia Negotiations
}

\section{Rinor Rexhepi ${ }^{1}$, Vigan Sahiti ${ }^{1}$}

${ }^{1}$ Universum College

St. Imzot Nikprelaj, Prishtina, 10000, Kosovo

DOI: $10.22178 /$ pos.69-3

LCC Subject Category:

HN50-995

Received 16.03.2021

Accepted 28.04.2021

Published online 30.04.2021

Corresponding Author: rexhepirinor172@gmail.com

(c) 2021 The Authors. This article is licensed under a Creative Commons Attribution 4.0 License (c) (1)

\begin{abstract}
Negotiations are forms of conversation, communication and bilateral or multilateral dialogue to resolve any kind of problem. Negotiations between Kosovo and Serbia are regional and global, as evidenced by the involvement of the EU and the US in these negotiations. The only way to finally resolve the problem between Kosovo and Serbia is dialogue. The purpose of the research is to analyse and measure Kosovo's opinion on resolving the problem with Serbia through dialogue and their opinion on Kosovo's representation in the talks and the agreement reached in Washington. The research was conducted through a questionnaire with structured questions, while a total of 470 respondents from all over Kosovo participated. Statistical analyses were analysed through the SPSS program, while qualitative ones through the inductive method. Based on the results, we see that demographic factors such as gender, age, and qualification affect the citizens of Kosovo's citizens to solve the problem with Serbia. Part of this research was also interviewing with experts on the Kosovo-Serbia dialogue. What we can recommend from this research is that dialogue should move from technical issues to political issues because the essence of this dialogue is political. The only way to its final solution is to reach an agreement that would include its resolution of all problems. The solution can be achieved through one of the possible scenarios in this paper in the theoretical and research part.
\end{abstract}

Keywords: negotiation; Kosovo-Serbia; representation; solution.

\section{INTRODUCTION}

On 17 February 2008, Kosovo declared its independence. Kosovo was declared a democratic republic based on separation of powers, control, and balance. Regulated by the constitution, Kosovo has four essential institutions: the President, the Government, Parliament, and the Constitutional Court. Kosovo's independence was declared in full compliance with the plan of Martti Ahtisaari, who had defined Kosovo as an independent and multiethnic state and consequently, the Constitution of Kosovo was built on the principles of this plan. According to the constitution, Kosovo is a state of Albanians and other communities, namely Bosnian Serbs, Turks, Roma, Ashkali, Egyptians and Gorani. The official languages in Kosovo are Albanian and Serbian.

From the first days, Kosovo's independence was recognised by many countries as the United States of America, Great Britain, Germany and Turkey. These were among the first recognitions, while nowadays, Kosovo officially counts a series of international recognitions. Since the declaration of independence, a robust diplomatic battle has been taking place between Kosovo and Serbia, where the first party tries to secure as much recognition as possible. In contrast, the other party tries to prevent at any cost the internationalisation of the state Kosovo. This opposition of Serbia had the support of some countries supporting its policies, such as Russia and China, which claim that the declaration of independence of Kosovo was contrary to the United Nations Charter (UN Resolution 1244), and the Helsinki Final Act, consequently contrary to the principles of international law.

Serbia constantly opposes the citizenship of Kosovo, while on the other hand, Kosovo promotes its citizenship. Relations between the two countries were and remain strained to this day. Seeing the situation, the European Union organised negotiations between these two parties to find a standard solution.

In this paper, we will address the negotiations between Kosovo and Serbia. We will talk about the agreements reached since 2013, the challenges of 
the dialogue and the difficulties that the implementation of the agreements has gone through.

Also, the involvement of the international community, led by the United States, in the negotiation process between Kosovo and Serbia will also be addressed. We will discuss possible scenarios and interpret the questionnaires conducted with citizens and interviews conducted with experts in the field.

\section{Literature review}

Negotiations are as old as the history of humanity itself. Negotiations are in the human nature of problem-solving; they are the fairest way to overcome various contradictions, inconsistencies or divergences. They approach solutions offered by different or opposing parties towards a compromise accepted by them and produces the most lasting agreement [1]. Negotiations are the best way to compromise. They are the mechanism for avoiding the deepening of problems, contradictions or conflicts; they are solutions that produce the most winners and the little losers. Negotiations are a product of the need to avoid tensions, contradictions, conflicts and wars [1]. In case of disagreement, there should be an agreement that all avenues lead to negotiations. Negotiations, in this case, are the best possible solution and brings the most reconciliation and results between the parties peacefully.

Negotiations stem from the need for peace and produce peace. They need to solve any problem between the parties through talks, exchanging ideas, to give proposals, and to promote bilateral or multilateral dialogue [1]. This need and necessity are also proven in the case of negotiations between Kosovo and Serbia.

The dialogue between Kosovo and Serbia has its origins in the UN General Assembly resolution (64/298), adopted in 2010. This resolution approved the ICJ opinion on the declaration of Kosovo's independence by its international law. In this resolution, the UN General Assembly called on the EU to initiate a dialogue between Kosovo and Serbia. Both the UN and the EU thought that dialogue should resolve the problems between Kosovo and Serbia [11].

Talks between Kosovo and Serbia on the normalisation of relations began in 2011; the European Union mediated these talks. The initial purpose of the Kosovo-Serbia dialogue was to resolve all outstanding issues between the two countries and potentially result in a legally binding agreement, which would end the protracted conflict by normalising relations between the two countries [5]. From the progress of the Belgrade-Pristina dialogue facilitated by the European Union [17], they have shown a more favourable climate for promoting tolerance and diversity between communities and between Kosovo Albanians and Kosovo Serbs [16].

The first political agreement between the two countries was reached in April 2013. This 15point agreement, for the most part, addresses the integration of the Serb community, especially the northern municipalities, through the association/community of Serb-majority municipalities, which according to the agreement, has full powers in many areas [13].

This agreement was considered the starting point of a long process of normalising relations between Kosovo and Serbia [3]. The 1 April 2013 Agreement on Principles Governing the Normalisation of Relations provides a solution to the conflict over the governance of Northern Kosovo. However, some agreement elements, such as establishing an Association of Serb-majority Municipalities in Kosovo, have not yet been implemented completely [4]. This agreement is seen by all parties involved as the primary outcome and culmination of this negotiation process in Brussels [9].

The main points of this agreement are [18]:

- establishment of an Association / Community of Serb-majority municipalities in Kosovo;

- the Association / Community will have complete oversight in the areas of economic development, education, health, urban and rural planning;

- in Kosovo, there will be the police force, called the Kosovo Police;

- all police in Northern Kosovo will be integrated into the Kosovo Police framework;

salaries will be only from KP;

- there will be a Regional Police Commander for the four northern Serb-majority municipalities (North Mitrovica, Zvecan, Zubin Potok and Leposavic);

- the commander of this region will be a Kosovo Serb nominated by the Ministry of Internal Affairs from the list provided by the four mayors on behalf of the Community / Association; 
- the composition of the KP in the north will reflect the ethnic composition of the population of the four municipalities (there will be another Regional Commander for the municipalities of South Mitrovica, Skënderaj and Vushtrri);

- the regional commander of the four northern municipalities will cooperate with other regional commanders;

- judicial authorities will be integrated and operate within the legal framework of Kosovo;

- an agreement that neither side will block, or encourage others to block, the other side's progress on the respective paths to the EU.

After reaching an agreement, the parties came up with various claims about its content. The Kosovo side claimed that the association of Serb-majority municipalities would have the competencies of an NGO, while the Serbian side stated that the association would have executive powers. The clash between the two sides over the competencies of the association provoked internal reactions in Kosovo politics. The Kosovar opposition strongly opposed this agreement, calling it harmful, which would create instability in Kosovo's functioning.

The implementation plan of the Brussels Agreement had foreseen deadlines that were not respected and the need for further political dialogue for the implementation of the same. Political developments in Kosovo and Serbia, the 2014 European Parliament elections, brought a new EU High Representative for Foreign Affairs and Security Policy, Ms Federica Mogherini, and a new attempt to resume dialogue. During 2015, under the chairmanship of the two former prime ministers of the two countries, Isa Mustafa and Aleksandar Vucic, Kosovo and Serbia had reached a block of agreements, deriving from the 19 April agreement [14]. The agreements that emerged from these meetings were different, such as the Agreement on Justice and the Judiciary, the agreement on the dissolution of the so-called 'Civil Protection', the agreement on the mutual recognition of vehicle insurance policies, Agreement on General Principles / Key Elements of the Association / Association of Serb Majority Municipalities, Conclusions on the implementation of the Energy Agreement of the year 2013, as well as the Telecommunications Action Plan [18].

The dialogue, in general, suffered major blows, especially with the engagement of Serbian diplomacy against the recognition of the state of Kosovo or its membership in international organisations such as UNESCO and INTERPOL, as well as the wall built on the Mitrovica bridge at a time when the opening of this bridge was expected. Also, the reactivation of international arrests by Serbia against citizens and senior officials of Kosovo strained relations between the two parties, leading to the suspension of dialogue by Kosovo [14]. The situation calmed down with the EU intervention, but it did not continue this trend for very long. The tense situation between the parties failed to calm down parties in March 2017, the Assembly of the Republic of Kosovo adopted a resolution requesting the suspension of the dialogue process until the release of the current Prime Minister of Kosovo, Mr Ramush Haradinaj, who was detained in France based on an arrest warrant issued by Serbia [15].

The period 2017-2018 has been full of tensions and incidents in bilateral relations between Kosovo and Serbia. However, all these challenges did not diminish the EU's commitment to encouraging both sides to return to continue the process of normalising relations between them [20]. The meetings in Brussels resumed on 3 July 2017, when the Presidents of Kosovo and Serbia, Hashim Thaçi and Aleksandar Vuçiç, met to agree that the dialogue should enter a new phase where more serious issues would be discussed and to move towards the conclusion of this process [6]. The parties returned to the table after the invitation of the EU to continue this process on 26 and 27 February 2018, where they discussed the implementation of agreements reached such as the agreement on freedom of movement, integrated border management, an association of municipalities with a Serb majority, justice, energy, and the Mitrovica bridge. The parties agreed to continue these meetings the following month. They also agreed that there would be no statement of their own after this meeting, but only an official statement of the EU on the progress of this process [7].

The culmination of the aggravation of reports until the disconnection of almost any communication occurred after Kosovo imposed a 100\% tariff on products imported from Serbia and Bosnia and Herzegovina on 21 November 2018. This tariff was set in response to the institutions of the Republic of Kosovo to Serbia's aggressive campaign to block Kosovo's membership in INTERPOL, as well as the latter's campaign to withdraw recognition of Kosovo [14] from the imposition of the tax occurred the severance of dialogue between the two countries. The question arose that the EU representative Mogehrini had allowed discussing the 
issue of redefining the territories and some other issues contrary to Kosovo's will.

The Brussels Dialogue has neither contributed to the strengthening of Kosovo's statehood from within nor to its consolidation from outside. The Republic of Kosovo continues to have difficulties in controlling and exercising sovereignty throughout its territory. In contrast, in the international arena, Kosovo continues to be blocked by Serbia in its efforts to join international organisations [17].

The direct involvement was formalised after the appointment of Matthew Palmer by the US State Department as Special Representative for the Balkans in August 2019 and the appointment of Richard Grenell as Special Envoy of the US President for reaching a peace agreement between the two countries. At the beginning of 2020, Kosovo and Serbia, under the direct mediation of the United States and Richard Grenell, had signed a series of new agreements in the form of letters of intent regarding the airline, railway and highway connecting two places. These agreements were proclaimed as an opportunity to continue the dialogue process towards reaching a final agreement based on the economic development model [14].

The government led by Prime Minister A. Kurti, formed in February 2020, formally expressed 'in favour of continuing the process, had refused the total abolition of the $100 \%$ tariff, without establishing reciprocity, contrary to what was required inconsistently and persistently from the top American officials, who were involved in this process.

Although the tariff was partially removed by a decision taken by the government on 20 March, this was assessed as insufficient by US officials, who even practically took the burden of concluding the dialogue process. The latter's request for complete and unconditional abolition of the tariff was ignored since, on $31 \mathrm{March}$, the incumbent government had decided to replace the tariff with reciprocity to Serbia. However, the government's decision to abolish the $100 \%$ tariff was supported by most EU countries and EU officials themselves [14].

With the coming to power of the Hoti government [A. Hoti], in the summer of 2020 , the dialogue continued but was characterised by problems because there were troubles in opening the topic of the association. Currently, the dialogue process between Kosovo and Serbia is blocked.
Paradoxically, with the EU calls for constructive cooperation in the spirit of normalising relations, the two sides have only deepened the differences between them [2]. Although the dialogue remains suspended, there is no initiative to build a political consensus in Kosovo with this other type. 100\% tariff, reciprocity, red lines and different attitude in the system community in this process are some elements that have influenced the political party not to reach a broader consensus on all other types related to the dialogue process [14].

In 2020, Kosovo with Prime Minister A. Hoti and Serbia with President A. Vucic had signed an agreement in the White House in the reception of US President Donald Trump. The agreement on the normalisation and international economic enterprise of Kosovo and Serbia is made as a move towards the normalisation of another average system. The main points that do not make me the implementation and skills for the construction of highways Belgrade - Pristina. Both sides must implement the Belgrade-Pristina railway agreement. The agreement also addresses the provision of finance to support loans required for small and medium-sized enterprises.

Part of this agreement is:

- entire international presence in Belgrade of the US International Corporation for Financial Development;

- operationalisation of the facility at the Merdare joint border crossing point;

- involvement of both parties in the "miniSchengen area", announced by Serbia, Albania and Northern Macedonia in October 2019;

- mutual recognition of diplomas and professional certificates;

- agreement of both parties to work with the Department of Energy of the US and other US Government entities in a feasibility study to share Lake Ujman as a safe supplier of water and energy.

Both sides have also pledged to multiply their energy sources. An essential point in this agreement for the geopolitical and economic interests of the US is also the commitment of both parties to ban the use of $5 \mathrm{G}$ devices, provided by incredible vendors, in their communication networks [10]. Also, an essential part of this meeting was the recognition of Kosovo by Israel.

The peculiarity of this agreement is that the negotiating parties have not signed an agreement with each other, but both separately with the US. This 
agreement also proves the significant role that the United States can play in the future in improving relations between Kosovo and Serbia and reaching a final reconciliation agreement.

\section{Possible options to reach an agreement}

As the parties consider the potential for an agreement, the three options presented below are likely to be possible options to reach an agreement without harming the negotiating parties.

Option one: Develop trade for recognition. Some hope that a combination of pressure, billions in development aid and investment for Serbia, along with the security of rapid EU membership, could lead to its recognition of Kosovo without significant concessions from Pristina [19]. Many opinions and forecasts have been given regarding the development of trade for recognition, but which are hesitant because if investments are made possible in Serbia and its membership in the EU can give wrong results and bring stalemate in developments. Twenty-seven countries must agree on EU membership. This is not a guarantee that can be used for Serbia, also when we know the situation of Serbia, which is not yet at that level to adapt to the level and conditions of the EU. However, "this scenario also raises the question (potentially important under the other options as well) of what would happen if Serbia became a member of the EU before Kosovo. Since any of the EU member states could block the admission of an applicant, if Serbia joins first, it would be able to climb the ladder before Pristina follows suit" [19].

Second option: Autonomy. A second compromise option would be modelled after other European countries approached minority grievances by giving them self-government in autonomous territories [8]. Through the second option, both countries Kosovo and Serbia, should give some autonomy to minorities within their territory. Kosovo has an issue with the association of municipalities. Thus, under this option, a Serb district comprising ten Serb-majority municipalities would have its constitution, assembly, police force, court, and funding source. Pristina would only deal with defence, foreign affairs, monetary policy and some law enforcement. The Presevo Valley would receive the same, or a similar set, of autonomous rights. In both countries, the autonomous district can also play a role in relations with the other state. The Serb entity receives Serbia and the Albanian entity from Kosovo [19].
Third option: Border modification (redefining). The third option for reaching a political solution between Pristina and Belgrade involves reciprocal border modifications, otherwise known as land swaps. Despite strong opposition from within the EU, supporters have for years argued that a territorial exchange could be vital to unblocking the Kosovo-Serbia dispute [12]. An enforceable agreement would integrate border changes into a comprehensive agreement, including mutual recognition, paving the way for Kosovo's membership in the UN and potentially opening the door to NATO and EU membership for Pristina, as well as Belgrade's EU membership.

Perhaps with the greatest possible attraction for both parties, an exchange would allow each to claim victory [19]. The people of Kosovo broadly welcome the redefinition of territories but often arouses fear among Serbs. The international community, led by Germany, does not see it as a good thing for geopolitical and regional reasons, which could lead to the destabilisation of Bosnia and Herzegovina. This may be the best possible option that is most supported, but that may not be resolved for use, but that the anticipated expectations are the continuation of the status quo in the future. Kosovo can make concessions only without the will of its people in other ways and solutions. Serbia is also aware that it refuses to give up Kosovo. So, the international community's involvement led by the US is seen as the most facilitating option for the final settlement between the two countries.

\section{Methodology}

The research belongs to the qualitative and quantitative type. The data were collected through a questionnaire distributed in Google Forms, while in the interviews, experts in the field of politics and diplomacy were interviewed.

A total of 470 respondents were included in the research, while their age, gender and qualification are according to a random sample. The age groups are from 18 to 65 years old. Participants were $58.9 \%$ male, while $41.1 \%$ female, while their qualification is from primary school to doctoral education. Dominant are the respondents with bachelor and master qualifications. The research lasted one calendar month. Initially, the data were coded in the program in SPSS (version 25). Questionnaire analyses were performed through descriptive statistical parameters (mean, standard deviation and 
their distribution). At the same time, the hypotheses were confirmed through ANOVA One and Two way and Independent Sample t-test. The independent variables are age group, gender and qualification. In contrast, the dependent variables are their opinion on the solution of the problem with Serbia through dialogue, the representation of Kosovo in the dialogue, and the citizens' opinion on the agreement in Washington.

The purpose of the research is to analyse the opinion of the citizens of Kosovo to the progress of the Kosovo-Serbia dialogue, to accurately measure the opinion of citizens on solving the problem through dialogue, Kosovo's representation in dialogue, and citizens' opinion on the Kosovo-Serbia agreement which is arrived in Washington. The research also includes interviews with experts on the Kosovo-Serbia dialogue process. We received their views on the US involvement in the dialogue, the development of the dialogue so far, and their opinion on the final epilogue of the dialogue.

\section{Hypotheses}

H01. There are significant differences between the age groups of citizens and their opinion on solving the problem between Kosovo and Serbia.

H02. There are significant differences between the level of education of citizens and their opinion on Kosovo's representation in dialogue with Serbia.

H03. There are significant gender differences in their opinion on dialogue and Kosovo's representation in dialogue.

\section{RESULTS AND DISCUSSION}

A total of 470 respondents participated in the research, while 129 of them belong to the age group 18-25 years or $27.4 \%$, 201 age group 26-35 years, 77 age group 36-44 years, then 40 respondents age group 45-54 years and 18 respondents of age group 55-65 years. Males are a total of 277 respondents, and 193 of the females. With primary education are two respondents or $0.4 \%, 99$ are with secondary education or $21.1 \%, 223$ respondents with bachelor education or 47.4\%, 127 with master or $27 \%, 15$ are with $\mathrm{PhD}$ qualification and four respondents with other qualifications as courses.
Over $67 \%$ of respondents think that the problems between Kosovo and Serbia should be resolved through dialogue.

Table 1 - Demographic results

\begin{tabular}{|l|c|c|}
\hline \multicolumn{1}{|c|}{ Age } & N & \% \\
\hline $18-25$ years old & 129 & 27.4 \\
\hline $26-35$ & 201 & 42.8 \\
\hline $36-44$ & 77 & 16.4 \\
\hline $45-54$ & 40 & 8.5 \\
\hline $55-65$ & 18 & 3.8 \\
\hline N/a Sex & 5 & 1.1 \\
\hline \multicolumn{1}{|c|}{ Level of education } & $\mathbf{N}$ & $\mathbf{\%}$ \\
\hline Male & $\mathbf{2 7 7}$ & 58.9 \\
\hline Female & 193 & 41.1 \\
\hline Elementary school & $\mathbf{\%}$ & 0.4 \\
\hline high school & 99 & 21.1 \\
\hline Bachelor & 223 & 47.4 \\
\hline Master & 127 & 27.0 \\
\hline PhD & 15 & 3.2 \\
\hline Other (Professional course) & 4 & 0.9 \\
\hline
\end{tabular}

In comparison, $16.2 \%$ have a negative opinion that this does not happen in the form of dialogue, and over $16 \%$ said they do not know. Only $7 \%$ of respondents think that Kosovo has been well represented in the dialogue with Serbia so far; $47 \%$ say that this has happened on average. In comparison, $44.5 \%$ say that there has been no excellent representation, and $1.5 \%$ do not know. Of the party that did not adhere to the agreement between Kosovo and Serbia, about 73\% think that Serbia is the one that does not respond to the dialogue, $2.6 \%$ say that this is happening because of Kosovo, 8.5\% do not know, and $15.5 \%$ of both parties together.

Table 2 - Opinion of the surveyed citizens regarding the Kosovo-Serbia dialogue

\begin{tabular}{|l|c|c|}
\hline $\begin{array}{l}\text { Do you think that dialogue will solve } \\
\text { the problems between Kosovo and } \\
\text { Serbia? }\end{array}$ & $\mathbf{N}$ & $\mathbf{\%}$ \\
\hline Yes & 317 & 67.4 \\
\hline No & 76 & 16.2 \\
\hline I don't know & 77 & 16.4 \\
\hline & & \\
\hline $\begin{array}{l}\text { Do you think that Kosovo has been } \\
\text { well represented in the dialogue with } \\
\text { Serbia so far? }\end{array}$ & $\mathbf{N}$ & $\mathbf{\%}$ \\
\hline Yes & 33 & 7.0 \\
\hline Average & 221 & 47.0 \\
\hline No & 209 & 44.5 \\
\hline & & \\
\hline
\end{tabular}




\begin{tabular}{|l|c|c|}
\hline I don't know & 7 & 1.5 \\
\hline $\begin{array}{l}\text { Which party do you think has not } \\
\text { adhered to the agreements reached in } \\
\text { the talks? }\end{array}$ & $\mathbf{N}$ & $\mathbf{\%}$ \\
\hline Kosovo & 12 & 2.6 \\
\hline I don't know & 40 & 8.5 \\
\hline Serbia & 345 & 73.4 \\
\hline Both of them & 73 & 15.5 \\
\hline
\end{tabular}

Over $90 \%$ of Kosovo citizens think that in case of non-implementation of the agreements reached, Kosovo should use protectionist measures such as taxes or reciprocity with Serbia. In comparison, $3.8 \%$ have the opposite opinion, while $5.1 \%$ say they do not know. Over $50 \%$ of citizens think that the United States of America should be a mediator in the dialogue between Kosovo and Serbia, 38\% say that both together, $4.7 \%$ the European Union, $2.8 \%$ neither and $1.1 \%$ say they do not know. Over $40 \%$ of Kosovo citizens see the agreement in Washington at an excellent average level, 8.5\% good, while over $35 \%$ say that this is a bad deal for Kosovo, while $13 \%$ said they do not know. As an epilogue of the Kosovo-Serbia dialogue, over 36\% see the redefinition of borders. In comparison, $26.8 \%$ Reciprocity in the rights of Albanians in Serbia with Serbs in Kosovo. In comparison, $21.3 \%$ say they do not know, $9.6 \%$ the association of municipalities, $5.1 \%$ the continuation of status quo, while others have very low percentages.

Table 3 - Citizens' opinion on the future of the Kosovo-

Serbia dialogue

\begin{tabular}{|l|c|c|}
\hline $\begin{array}{l}\text { In case of non-implementation of } \\
\text { the agreements reached in the } \\
\text { dialogue, should Kosovo use } \\
\text { protectionist measures (taxes, } \\
\text { reciprocity) against Serbia? }\end{array}$ & $\mathbf{N}$ & $\mathbf{\%}$ \\
\hline Yes & 428 & 91.1 \\
\hline No & 18 & 3.8 \\
\hline I don't know & 24 & 5.1 \\
\hline & $\mathbf{N}$ & $\mathbf{\%}$ \\
\hline $\begin{array}{l}\text { Who do you think should be the } \\
\text { mediator in the Kosovo-Serbia } \\
\text { dialogue? }\end{array}$ & 13 & 2.8 \\
\hline Neither & 22 & 4.7 \\
\hline European union & 5 & 1.1 \\
\hline I don't know & 250 & 53.2 \\
\hline United States & 180 & 38.3 \\
\hline Both together & & \\
\hline & & \\
\hline
\end{tabular}

\begin{tabular}{|l|c|c|}
\hline $\begin{array}{l}\text { How do you see the agreement } \\
\text { reached in Washington between } \\
\text { Kosovo and Serbia by the Trump } \\
\text { administration? }\end{array}$ & $\mathbf{N}$ & $\mathbf{\%}$ \\
\hline Good & 40 & 8.5 \\
\hline Moderately good & 203 & 43.2 \\
\hline Bad & 166 & 35.3 \\
\hline I don't know & 61 & 13.0 \\
\hline & & \\
\hline $\begin{array}{l}\text { Which of the following scenarios do } \\
\text { you think will be the epilogue of the } \\
\text { Kosovo-Serbia dialogue? }\end{array}$ & $\mathbf{N}$ & $\mathbf{\%}$ \\
\hline $\begin{array}{l}\text { Association of Serb-majority } \\
\text { municipalities }\end{array}$ & 45 & 9,6 \\
\hline $\begin{array}{l}\text { So far, there have been no } \\
\text { negotiations (dialogue) but only } \\
\text { fulfilled the wishes of Serbia. }\end{array}$ & 1 & 0,2 \\
\hline $\begin{array}{l}\text { The agreement imposed by the EU / } \\
\text { US with bitter compromises for both } \\
\text { parties! }\end{array}$ & 1 & 0,2 \\
\hline Normalisation agreement. & 1 & 0,2 \\
\hline Final recognition by Serbia & 1 & 0,2 \\
\hline Mutual recognition & 2 & 0,4 \\
\hline $\begin{array}{l}\text { Reciprocity of rights of Albanians in } \\
\text { Serbia with Serbs in Kosovo }\end{array}$ & 126 & 26.8 \\
\hline $\begin{array}{l}\text { They are redefining the borders (the } \\
\text { Albanian part of Presevo, Bujanovac } \\
\text { and Medvedja to join Kosovo and the } \\
\text { Serbian part of Leposavic, Zvecan and } \\
\text { Zubin Potok to join Serbia. }\end{array}$ & 165 & 36,1 \\
\hline Continuation of the status quo & 24 & 5,1 \\
\hline $\begin{array}{l}\text { It is difficult to give an opinion as the } \\
\text { negotiations have been very } \\
\text { unfavourable for Kosovo, and the } \\
\text { other side has been advantageous. }\end{array}$ & 1 & 0,2 \\
\hline I don't know & 100 & 21,3 \\
\hline $\begin{array}{l}\text { It depends on the empowerment of } \\
\text { the Far East and Russia and the US } \\
\text { bypassing us }\end{array}$ & 1 & 0,2 \\
\hline $\begin{array}{l}\text { I do not know what will happen! } \\
\text { Redefining boundaries would be the } \\
\text { permanent solution }\end{array}$ & 1 \\
\hline Only in favour of Serbia & 0,2 \\
\hline
\end{tabular}

\section{Verification of hypotheses}

H01. There are significant differences between the age groups of citizens and their opinion on solving the problem between Kosovo and Serbia.

We have used the ANOVA One Way test to confirm the above hypothesis, where the independent variable is the age group. In contrast, the dependent variable is the opinion of the citizens on solving problems with Serbia through dialogue. 
Table 4 - Do you think that the problems between Kosovo and Serbia will be solved through dialogue? (Descriptive)

\begin{tabular}{|c|c|c|c|c|c|c|c|c|}
\hline \multirow{2}{*}{ Year } & \multirow{2}{*}{$\mathrm{N}$} & \multirow{2}{*}{ Mean } & \multirow{2}{*}{ Std. Deviation } & \multirow{2}{*}{ Std. Error } & \multicolumn{2}{|c|}{ 95\% Confidence Interval for Mean } & \multirow{2}{*}{ Minimum } & \multirow{2}{*}{ Maximum } \\
\hline & & & & & Lower Bound & Upper Bound & & \\
\hline $18-25$ & 129 & 1.67 & 0.832 & 0.073 & 1.52 & 1.81 & 1 & 3 \\
\hline $26-35$ & 201 & 1.42 & 0.725 & 0.051 & 1.32 & 1.52 & 1 & 3 \\
\hline $36-44$ & 77 & 1.47 & 0.771 & 0.088 & 1.29 & 1.64 & 1 & 3 \\
\hline $45-54$ & 40 & 1.28 & 0.599 & 0.095 & 1.08 & 1.47 & 1 & 3 \\
\hline $55-65$ & 18 & 1.61 & 0.778 & 0.183 & 1.22 & 2.00 & 1 & 3 \\
\hline Total & 465 & 1.49 & 0.763 & 0.035 & 1.42 & 1.56 & 1 & 3 \\
\hline
\end{tabular}

Based on the above results, we see that in the age group 15-25 are 129 respondents with an average of their opinion 1.67 (which is between Yes and No), while the age group 26-35 has an average of 1.42 , the 36-44 age group has an average of 1.47 , the 45-54 age group has an average of 1.28 , and the 55-65 age group has an average of 1.61 .

Table 5 - Do you think that the problems between Kosovo and Serbia will be solved through dialogue? (ANOVA)

\begin{tabular}{|l|c|c|c|c|c|}
\hline & $\begin{array}{c}\text { Sum of } \\
\text { Squares }\end{array}$ & df & $\begin{array}{c}\text { Mean } \\
\text { Square }\end{array}$ & F & Sig. \\
\hline $\begin{array}{l}\text { Between } \\
\text { Groups }\end{array}$ & 7.081 & 4 & 1.770 & 3.094 & 0.016 \\
\hline $\begin{array}{l}\text { Within } \\
\text { Groups }\end{array}$ & 263.143 & 460 & 0.572 & & \\
\hline Total & 270.224 & 464 & & & \\
\hline
\end{tabular}

The results of the ANOVA test show that we have a degree of freedom $\mathrm{DF}=460$, square means of
1.770, the test of statistical significance $F=3.094$, and $p$-value $=0.016$, which is significant at $0.05 \%$ of the level of reliability.

In this case, we say that statistically, age is a factor that influences the opinion of citizens on solving the problem with Serbia through dialogue. Those who are older have a more positive level towards problem-solving through dialogue, while a similarity has the age groups $26-35$ and 36-44 years.

So, we accept the hypothesis and say that there are significant differences between the age groups of citizens and their opinion on solving the problem between Kosovo and Serbia, p-value $<0.05 \%$.

H02. There are significant differences between the level of education of citizens and their opinion on Kosovo's representation in dialogue with Serbia.

We used the ANOVA One Way test to confirm the above hypothesis, where the independent variable is education. At the same time, the dependent one is the opinion of the citizens on solving the problem with Serbia through dialogue.

Table 6 - Do you think that through dialogue, the problems between Kosovo and Serbia will be solved (Descriptive)

\begin{tabular}{|c|c|c|c|c|c|c|c|c|}
\hline & \multirow[t]{2}{*}{$\mathrm{N}$} & \multirow[t]{2}{*}{ Mean } & \multirow{2}{*}{$\begin{array}{c}\text { Std. } \\
\text { Deviation }\end{array}$} & \multirow{2}{*}{$\begin{array}{l}\text { Std. } \\
\text { Error }\end{array}$} & \multicolumn{2}{|c|}{$\begin{array}{c}\text { 95\% Confidence Interval for } \\
\text { Mean }\end{array}$} & \multirow[t]{2}{*}{ Minimum } & \multirow[t]{2}{*}{ Maximum } \\
\hline & & & & & Lower Bound & Upper Bound & & \\
\hline Elementary school & 2 & 2.50 & 0.707 & 0.500 & -3.85 & 8.85 & 2 & 3 \\
\hline Hight School & 99 & 1.60 & 0.768 & 0.077 & 1.44 & 1.75 & 1 & 3 \\
\hline Bachelor & 223 & 1.60 & 0.826 & 0.055 & 1.49 & 1.71 & 1 & 3 \\
\hline Master & 127 & 1.22 & 0.548 & 0.049 & 1.12 & 1.32 & 1 & 3 \\
\hline $\mathrm{PhD}$ & 15 & 1.20 & 0.561 & 0.145 & 0.89 & 1.51 & 1 & 3 \\
\hline $\begin{array}{l}\text { Others (professional } \\
\text { course) }\end{array}$ & 4 & 1.75 & 0.957 & 0.479 & 0.23 & 3.27 & 1 & 3 \\
\hline Total & 470 & 1.49 & 0.761 & 0.035 & 1.42 & 1.56 & 1 & 3 \\
\hline
\end{tabular}

The above results show that respondents with primary qualification have an opinion much farther from other groups with an average of 2.50 . Respondents with secondary qualification have an average of their opinion of 1.60. Respondents with bachelor qualifications have an opinion on solving the problem with an average of 1.60; master has an average of $1.22, \mathrm{PhD} 1.20$, and those with other qualification have an average of 1.75 . 
Table 7 - Do you think that the problems between Kosovo and Serbia will be solved through dialogue? (ANOVA)

\begin{tabular}{|l|c|c|c|c|c|}
\hline & $\begin{array}{c}\text { Sum of } \\
\text { Squares }\end{array}$ & df & $\begin{array}{c}\text { Mean } \\
\text { Square }\end{array}$ & F & Sig. \\
\hline $\begin{array}{l}\text { Between } \\
\text { Groups }\end{array}$ & 16.652 & 5 & 3.330 & 6.065 & 0.000 \\
\hline $\begin{array}{l}\text { Within } \\
\text { Groups }\end{array}$ & 254.795 & 464 & 0.549 & & \\
\hline Total & 271.447 & 469 & & & \\
\hline
\end{tabular}

The results of the ANOVA test show that we have a degree of freedom $\mathrm{DF}=469$, average in squares of 3,330 , test $F=6.065$ and $p$-value $=0.000$, which is significant at $0.01 \%$ of the level of reliability. In this case, we say that the respondents with master and $\mathrm{PhD}$ qualification have a more approximate opinion, while the difference lies in the other groups. So, we accept the hypothesis and say that there are significant differences between the level of education of citizens and their opinion on the representation of Kosovo in dialogue with Serbia p-value $<0.01 \%$.

H03. There are significant gender differences in their opinion on resolving dialogue and Kosovo's representation in dialogue.

To confirm the above hypothesis, we used the Independent Sample T-test. At the same time, the independent variable is gender, and the dependent variables are the opinion of citizens on solving problems with Serbia through dialogue and their opinion on Kosovo's representation in dialogue with Serbia.

Table 8 - Do you think that the problems between Kosovo and Serbia will be solved through dialogue? (Group Statistics)

\begin{tabular}{|l|c|c|c|c|c|}
\hline & Gender & N & Mean & $\begin{array}{c}\text { Std. } \\
\text { Deviation }\end{array}$ & $\begin{array}{c}\text { Std. Error } \\
\text { Mean }\end{array}$ \\
\hline $\begin{array}{l}\text { Do you think that through dialogue, the problems between } \\
\text { Kosovo and Serbia will be solved? }\end{array}$ & Male & 277 & 1.44 & 0.702 & 0.042 \\
\cline { 2 - 6 } & Female & 193 & 1.56 & 0.834 & 0.060 \\
\hline $\begin{array}{l}\text { Do you think that Kosovo has been well represented in the } \\
\text { dialogue with Serbia until now? }\end{array}$ & Male & 277 & 2.28 & 0.608 & 0.037 \\
\cline { 2 - 6 } & Female & 193 & 2.58 & 0.650 & 0.047 \\
\hline
\end{tabular}

The above results show that in their opinion on the resolution of the dialogue with Serbia, men have an average of 1.44 and a standard deviation of 0.70 , while women 1.56 and a standard deviation of 0.83 .

Table 9 - Do you think that the problems between Kosovo and Serbia will be solved through dialogue? (Independent Samples Test)

\begin{tabular}{|c|c|c|c|c|c|c|c|c|c|c|}
\hline & \multicolumn{2}{|c|}{$\begin{array}{c}\text { Levene's Test for } \\
\text { Equality of } \\
\text { Variances }\end{array}$} & \multicolumn{7}{|c|}{ t-test for Equality of Means } \\
\hline & & \multirow[t]{2}{*}{ 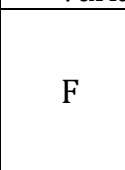 } & \multirow[t]{2}{*}{ Sig. } & \multirow[t]{2}{*}{$\mathrm{t}$} & \multirow[t]{2}{*}{ df } & \multirow[t]{2}{*}{$\begin{array}{l}\text { Sig. (2- } \\
\text { tailed) }\end{array}$} & \multirow[t]{2}{*}{$\begin{array}{c}\text { Mean } \\
\text { Difference }\end{array}$} & \multirow[t]{2}{*}{$\begin{array}{l}\text { Std. Error } \\
\text { Difference }\end{array}$} & \multicolumn{2}{|c|}{$\begin{array}{l}95 \% \text { Confidence } \\
\text { Interval of the } \\
\text { Difference }\end{array}$} \\
\hline & & & & & & & & & Lower & Upper \\
\hline \multirow{2}{*}{$\begin{array}{l}\text { Do you think that } \\
\text { through dialogue, the } \\
\text { problems between } \\
\text { Kosovo and Serbia will } \\
\text { be solved? }\end{array}$} & \begin{tabular}{|l} 
Equal \\
variances \\
assumed
\end{tabular} & 17.390 & 0.000 & -1.798 & 468 & 0.073 & -0.128 & 0.071 & -0.268 & 0.012 \\
\hline & \begin{tabular}{|l|} 
Equal \\
variances \\
not \\
assumed
\end{tabular} & & & -1.744 & 366.499 & 0.082 & -0.128 & 0.073 & -0.272 & 0.016 \\
\hline \multirow{2}{*}{$\begin{array}{l}\text { Do you think that } \\
\text { Kosovo has been well } \\
\text { represented in the } \\
\text { dialogue with Serbia } \\
\text { until now? }\end{array}$} & \begin{tabular}{|l} 
Equal \\
variances \\
assumed
\end{tabular} & 3.083 & 0.080 & -5.094 & 468 & 0.000 & -0.299 & 0.059 & -0.414 & -0.183 \\
\hline & \begin{tabular}{|l|} 
Equal \\
variances \\
not \\
assumed
\end{tabular} & & & -5.034 & 395.467 & 0.000 & -0.299 & 0.059 & -0.415 & -0.182 \\
\hline
\end{tabular}


In their opinion on the representation of Kosovo in the dialogue, we see that men have an average of 2.28 and a standard deviation of 0.60 , and women have an average of 2.58 and a standard deviation of 0.65 .

The above results show that in the opinion of citizens on problem-solving through dialogue, we have the test $\mathrm{F}=17.390$, degree of freedom $\mathrm{DF}=366.49$. $\mathrm{P}$-value=0.082 above the level of credibility of $0.05 \%$. We say that we do not have Significant gender differences in terms of their opinion on solving the problem with Serbia through dialogue. In contrast, in their opinion on the representation of Kosovo, we see that we have test $F=3.083$, degree of freedom of 395.46 and $p$ wave $=.000$, which is significant at $0.01 \%$ reliability. In the first case, both genders have a similar opinion, both men and women, while in the second case in representation, women have a more negative opinion than men.

In this case, we partially accept the hypothesis and say that there are significant gender differences in their opinion on Kosovo's representation in dialogue. Still, there are no significant gender differences to problem-solving with Serbia through dialogue.

Table 12 - Interviews with experts for negotiations Kosovo-Serbia

\begin{tabular}{|c|c|c|}
\hline Category & Preliminary interpretation & Text \\
\hline $\begin{array}{l}\text { 1. How do you see } \\
\text { the US } \\
\text { involvement in } \\
\text { the Kosovo-Serbia } \\
\text { dialogue? }\end{array}$ & $\begin{array}{l}\text { According to the interviewees, the US has } \\
\text { been involved in the dialogue since the } \\
\text { Rambouillet Talks, the Vienna Talks on the } \\
\text { settlement of the final status and the } \\
\text { Brussels Talks. The involvement of the US } \\
\text { in these talks will give clarity to the } \\
\text { dialogue and another pace, and this will } \\
\text { happen in coordination with the EU and } \\
\text { accelerate the achievement of a final } \\
\text { agreement by resolving the problems } \\
\text { between Kosovo and Serbia. US } \\
\text { participation in the dialogue means to } \\
\text { support and security for Kosovo. The US } \\
\text { has left open any possibility and possible } \\
\text { scenario that the parties agree to be the } \\
\text { final solution. }\end{array}$ & $\begin{array}{l}\text { AK. The US has been fully involved in the } \\
\text { Kosovo-Serbia talks before. The role and } \\
\text { involvement of the United States have been } \\
\text { crucial in the Rambouillet, Vienna and, most } \\
\text { recently, Brussels talks. In the last two or } \\
\text { three years, we have seen no change of } \\
\text { format or a shift in the talks from Brussels } \\
\text { to Washington. Still, a change of course } \\
\text { towards resolving the remaining problems } \\
\text { between Kosovo and Serbia after Kosovo } \\
\text { declares independence. If until two or three } \\
\text { years ago, the only option in the talks was a } \\
\text { multiethnic Kosovo and the accommodation } \\
\text { of the Serb minority in Kosovo, now at least } \\
\text { Washington and any European country } \\
\text { have left open the possibility of exchanging } \\
\text { territory between Kosovo and Serbia. To } \\
\text { finally resolve the problems between } \\
\text { Albanians and Serbs and Serbia to get rid of } \\
\text { this problem and get a visa for the } \\
\text { complicated EU accession process and its } \\
\text { secession from Russian influence. Some } \\
\text { European countries did not agree with this } \\
\text { new American strategy. Still, especially } \\
\text { Germany, therefore, came the US insistence } \\
\text { long-term dialogue framework. In this } \\
\text { context, a comprehensive agreement } \\
\text { between Kosovo and Serbia will be } \\
\text { talks and convince the parties for a final } \\
\text { solution to the Kosovo problems -Serbi. Of } \\
\text { course, in public, this seemed like a US } \\
\text { reawakening. But the truth is that the US } \\
\text { has once again been the actual creator of } \\
\text { talks and agreements like in Rambouillet, } \\
\text { Vienna and Brussels. } \\
\text { DA. US involvement in the Kosovo-Serbia } \\
\text { dee would give the dialogue clarity, } \\
\text { paringer }\end{array}$ \\
\hline
\end{tabular}




\begin{tabular}{|c|c|c|}
\hline Category & Preliminary interpretation & Text \\
\hline & & $\begin{array}{l}\text { accelerated, with the final goal of mutual } \\
\text { recognition. } \\
\text { VY. US involvement in the Kosovo-Serbia } \\
\text { dialogue has been good news for the region } \\
\text { and especially for Kosovo. Given Kosovo's } \\
\text { long-term alliance with the United States, } \\
\text { their involvement in the dialogue implies } \\
\text { strong support for Kosovo and our } \\
\text { sovereignty. But it is also suitable for the } \\
\text { region as the US is the guarantor of regional } \\
\text { peace and stability. At the same time, } \\
\text { without their economic and diplomatic } \\
\text { power, there is no other party that can then } \\
\text { manage to impose the implementation of } \\
\text { the agreement between Kosovo and Serbia. } \\
\text { However, the unilateral and sometimes } \\
\text { exclusionary leadership of White House } \\
\text { envoy Richard Grenell has caused great } \\
\text { confusion in Kosovo and the EU. }\end{array}$ \\
\hline $\begin{array}{l}\text { 2. How do you see } \\
\text { the development } \\
\text { of the Kosovo- } \\
\text { Serbia dialogue } \\
\text { until now? }\end{array}$ & $\begin{array}{l}\text { Respondents think that these talks have } \\
\text { had some minor successes but are } \\
\text { essentially failed because both parties did } \\
\text { not enter these talks in complete } \\
\text { seriousness. As a result, the talks } \\
\text { themselves did not meet their } \\
\text { expectations, leaving much uncertainty for } \\
\text { their future. In general, in this dialogue, the } \\
\text { parties have dealt with technical issues } \\
\text { bypassing the essence of the problem, } \\
\text { which is political, even the political } \\
\text { agreements that have been reached have } \\
\text { not been implemented due to } \\
\text { dissatisfaction and controversy between } \\
\text { the parties, a concrete example is an } \\
\text { agreement on the association of majority } \\
\text { municipalities Serbian. }\end{array}$ & $\begin{array}{l}\text { AK. These talks were initially destined to } \\
\text { fail. I say so by looking at and analysing the } \\
\text { direction they took. Both sides did not enter } \\
\text { these talks with due seriousness; both sides } \\
\text { have agreed to negotiate only because this } \\
\text { has been requested by the international } \\
\text { community, namely the US. Given this (and } \\
\text { this has been the case), the talks have not } \\
\text { touched at all (at least not yet) the real } \\
\text { problems that Kosovo and Serbia have, } \\
\text { without the solution of which there can be } \\
\text { no final solution, there can be no lasting } \\
\text { peace, there can be no mutual recognition, } \\
\text { and consequently, there can be no full } \\
\text { integration into international mechanisms, } \\
\text { especially not in the EU. } \\
\text { DA. So far, there have been minor successes. } \\
\text { However, the development and conclusion } \\
\text { of the dialogue require a more precise and } \\
\text { in-depth clarification of the content. We can } \\
\text { say that so far, in a symbolic form, the } \\
\text { dialogue has not even completed the } \\
\text { elementary level because there is a lot of } \\
\text { uncertainty about the future of both } \\
\text { countries. } \\
\text { VY. The Normalisation Dialogue held in } \\
\text { Brussels has reached its limits, and there } \\
\text { have been significant problems. The major } \\
\text { problem is that it has been a dialogue that } \\
\text { has dealt with 'technical' issues and focused } \\
\text { on various agreements on various issues, } \\
\text { thus avoiding the core of the political } \\
\text { problem. Therefore, in this area, we have } \\
\text { had more complex arrangements which } \\
\text { have caused harm (like the one to the } \\
\text { Association of Municipalities) without } \\
\text { bringing any benefit and progress in the } \\
\text { relations between the two countries. }\end{array}$ \\
\hline
\end{tabular}




\begin{tabular}{|c|c|c|}
\hline Category & Preliminary interpretation & Text \\
\hline $\begin{array}{l}\text { 3. What do you } \\
\text { think will be the } \\
\text { final epilogue of } \\
\text { the talks? }\end{array}$ & $\begin{array}{l}\text { The parties have different opinions } \\
\text { regarding the final epilogue. Some think } \\
\text { the final solution will be to redefine the } \\
\text { borders between Kosovo and Serbia. And } \\
\text { that this redefinition of borders would } \\
\text { create a permanent and lasting solution } \\
\text { between the parties. Another solution is to } \\
\text { implement the association of Serb- } \\
\text { majority municipalities, but the question } \\
\text { will be about the type of competencies that } \\
\text { this association will have. Another } \\
\text { dilemma that the interviewees have is } \\
\text { whether there will be reciprocal } \\
\text { recognition after establishing the } \\
\text { association. To recognise Kosovo, Serbia } \\
\text { must make constitutional changes because } \\
\text { Kosovo is a territorial part of Serbia within } \\
\text { its constitution. In this regard, the EU, } \\
\text { during the integration process, should put } \\
\text { pressure on the Serbian state to change } \\
\text { the constitution because no state can join } \\
\text { the EU if there is a territorial dispute with } \\
\text { a neighbouring state. }\end{array}$ & 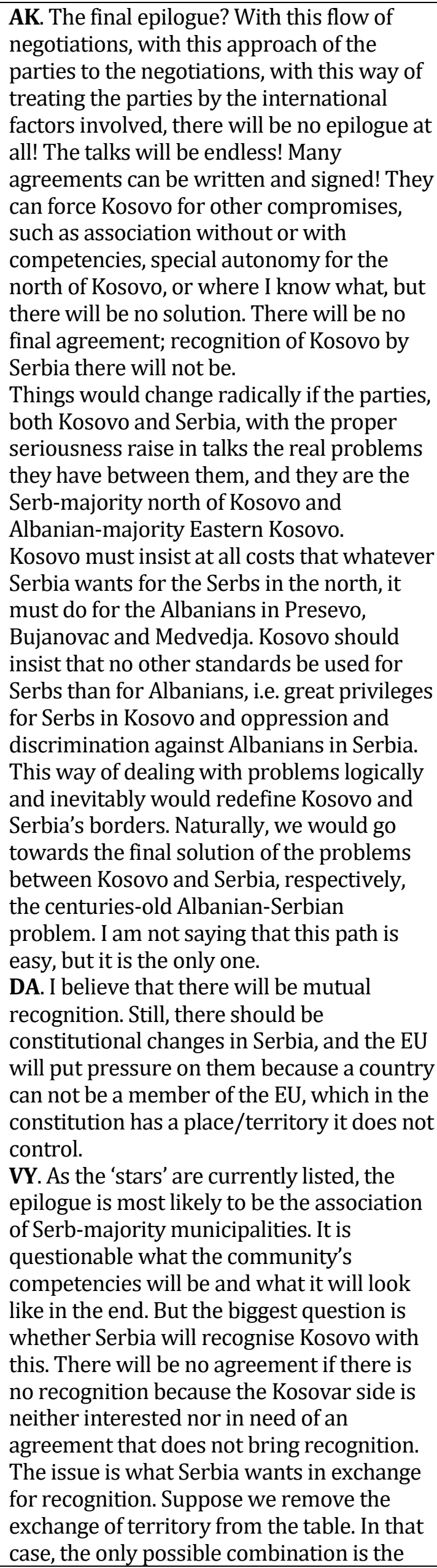 \\
\hline
\end{tabular}




\begin{tabular}{|l|l|l|}
\hline Category & \multicolumn{1}{|c|}{ Preliminary interpretation } & \multicolumn{1}{|c|}{ Text } \\
\hline & & $\begin{array}{l}\text { community with regional integration (Mini } \\
\text { Schengen) that will make Belgrade the } \\
\text { regional capital. In this way, Serbia will } \\
\text { adopt a kind of autonomy for the Serbs in } \\
\text { Kosovo, do these avoid the borders of the } \\
\text { Serbs in Serbia entirely, there in the }\end{array}$ \\
& $\begin{array}{l}\text { Republika Srpska in Bosnia and the Serbs in } \\
\text { Kosovo. And that will be enough for Serbia } \\
\text { to recognise Kosovo's independence. On the } \\
\text { other hand, by completely removing the } \\
\text { borders between them, the Albanians will } \\
\text { organise the 'Albanosphere' unhindered and } \\
\text { with significant economic, political, social } \\
\text { and cultural potential. }\end{array}$ \\
\hline
\end{tabular}

\section{Final interpretation of interviews}

Topic 1. Involvement of the USA in the KosovoSerbia dialogue. Since the time of Rambouillet, the US has been involved in the Kosovo-Serbia dialogue, the final status negotiations in Vienna, the Brussels dialogue, and the Washington meeting. In all these negotiations, the US has played a vital role. It is the main economic and diplomatic power, which can help reach a final solution between the parties and be the guarantor of the agreement's implementation. The US has left open the possibility of any agreement the parties agree on, each of the possible scenarios outlined above. The novelty in these talks is precisely the opening of new alternatives for reaching an agreement, including the option of redefining the borders of both parties. The United States' involvement in the dialogue brings Kosovo more security (because the United States has been the primary supporter of Kosovo's independence) and can accelerate negotiations, positively affecting a final agreement. For the US, the Balkans is an area of particular interest, and therefore they will contribute to these talks to create stability in the Western Balkans.

Topic 2. Kosovo-Serbia dialogue until now. Although there have been some minor successes in this dialogue, in essence, this dialogue cannot be considered successful for several reasons. First, the parties were forced to enter into a dialogue against their will, as a result of which there was no sincere attempt by the parties to reconcile their positions. The other reason is that the parties have run away from hot, substantive issues, dealing with secondary issues. So, the parties are engaged in technical talks, avoiding political ones, which are also the core of the dispute. But even those technical level agreements and the few political level agreements (association of Serb-majority municipalities) that have been reached have not been fully or completely implemented. So, due to these factors, negotiations have stalled with no improvement in relations between the two countries. Thus, the Kosovo-Serbia negotiations must be oriented towards political problems to reach an agreement that is final and acceptable to both parties.

Topic 3. The final epilogue of the agreement. As the dialogue has developed so far, it is difficult to reach an agreement that would finally solve the problem between the two countries. But with US involvement, the dialogue could take a different turn. Since the US is more open to accepting any agreement acceptable to both parties, the parties can also negotiate other options for reaching a final agreement. Three main options can be seen as an epilogue to the final agreement:

1. Redefining the borders between Kosovo and Serbia, where the Albanian part of Presevo, Bujanovac and Medvedja join Kosovo; and the Serb part of Leposavic, Zvecan and Zubin Potok to join Serbia, and to remove the restrictions imposed by the Kosovo constitution from the Ahtisaari Package

2. Remaining existing borders but establishing an association of Serb-majority municipalities with or without executive powers

3. Mutual acquaintance with existing borders. As well as the last option which is less favourable, that of continuing the status quo.

\section{CONCLUSIONS}

We can say that the citizens of Kosovo have explicit opinions regarding their opinion on the 
solution of the problem with Serbia, which they think should be resolved through dialogue. They do not see the representation of Kosovo at all well. According to the interviewed citizens, the culprit for the non-implementation of the agreements is Serbia, which is not adhering to them. As a result, reciprocity and taxes are seen as a solution. Kosovo citizens see the US as a critical factor in the Kosovo-Serbia dialogue and see the Washington agreement as moderately good. Regarding the final epilogue, most citizens think that redefining the borders would be the best solution.

What we can recommend from this research is that the dialogue should move from the technical to the political level because the problem between the two countries is political. The parties must also compromise to reach an agreement acceptable to both countries because, in negotiations, there is rarely an ideal solution that meets the maximum expectations of the parties. Also, the involvement of the US in these negotiations is more than necessary because it changes the negotiating spirit and enables the parties to find an acceptable agreement, allowing the parties to negotiate for other options which have not been previously accepted. Based on the majority of the surveyed citizens and the research done by us, we think that a satisfactory agreement that would solve the problem between Kosovo and Serbia once and for all would redefine the borders between the two countries.

\section{REFERENCES}

1. Bashkurti, L. (2007). Negociatat, historia, teoria, praktika. Tiranë: Geer.

2. Bashota, B., \& Dugolli, B. (2019). Kosovo- Serbia Agreements between Creative and Destructive Ambiguity. UNISCI Journal, 17(50), 125-149. doi: 10.31439/unisci-52

3. Beha, A. (2015). Disputes over the 15-point agreement on normalization of relations between Kosovo and Serbia. Nationalities Papers, 43(1), 102-121. doi: 10.1080/00905992.2014.990367

4. Bergmann, J. (2018). Same Table, Different Menus? A Comparison of UN and EU Mediation Practice in the Kosovo-Serbia Conflict. International Negotiation, 23(2), 238-257. doi: 10.1163/15718069-23021156

5. Bieber, F. (2015). The Serbia-Kosovo Agreements: An eu Success Story? Review of Central and East European Law, 40(3-4), 285-319. doi: 10.1163/15730352-04003008

6. European External Action Service. (2017, July 3). Federica Mogherini meets with President Vučić of Serbia and Thaçi of Kosovo. Retrieved from https://eeas.europa.eu/headquarters/headquartershomepage/29156/federica-mogherini-meets-president-vu\%C4\%8Di\%C4\%87-serbia-andtha\%C3\%A7i-kosovo_en

7. European External Action Service. (2018, February 27). Statement by the Spokesperson following the working level meeting within the EU facilitated Dialogue. Retrieved from https://eeas.europa.eu/headquarters/headquarters-homepage/40471/statementspokesperson-follo\%C3\%ABing-\%C3\%ABorking-level-meeting-\%C3\%ABithin-eu-facilitateddialogue_en

8. Freedom House. (2020). Freedom in the World 2020. Serbia. Retrieved March 1, 2021, from https://freedomhouse.org/country/serbia/freedom-world/2020

9. Gashi, K., Musliu, V., \& Orbie, J. (2017). Mediation Through Recontextualization: The European Union and The Dialogue Between Kosovo and Serbia. European Foreign Affairs Review, 22(4), 533-550.

10. Gearan, A. (2020, September 5). Serbia and Kosovo sign breakthrough economic accord that is short of normal relations. The Washington Post. Retrieved from https://www.washingtonpost.com/politics/trump-kosovo-serbiaagreement/2020/09/04/b1283f8c-eec0-11ea-99a1-71343d03bc29_story.html

11. Hoxhaj, E. (2016). Establishment of a state. Pristina: Dudaj Press.

12. Huszka, B. (2018, November 14). A high risk, high reward gamble: What are the benefits of a KosovoSerbia land-swap? Retrieved from https://blogs.lse.ac.uk/europpblog/2018/11/14/a-high-risk- 
high-reward-gamble-what-are-the-benefits-of-a-kosovo-serbia-land-

swap/\#: :text=The\%20arguments\%20in\%20favour\%20of,Kosovo\%20without\%20some\%20s erious $\% 20$ concessions.

13. Kosova Democratic Institute. (2018, March). DIALOGU KOSOVË - SERBI: SFIDAT DHE RRUGA

PËRPARA. Retrieved from https://kdi-kosova.org/wp-content/uploads/2018/03/18-SfidatFINAL-ALB-

06.pdf?fbclid=IwAR3cGuVPk2TpRF64lc21ff_aVlRnBsVrvnQDWRcqIj_f9z8rKYX90dfPYqs

14. Kosova Democratic Institute. (2020, April). 7 VITE PAS MARRËVESHJES SË PARË PËR NORMALIZIM: KU JANË KOSOVA DHE SERBIA ME "NORMALIZIM" SOT? Retrieved from https://kdikosova.org/wp-content/uploads/2020/04/28-7-Vite-pas-marreveshjes-se-pare-pernormalizim-Kosove-Serbi-Raport-03.pdf

15. Lidhur me ndalimin e ish-kryeministrit të Kosovës, z. Ramush Haradinaj, në Francë (Republic of Kosovo), 10.03.2017, No 05-R-11. Retrieved March 1, 2021, from http://old.kuvendikosoves.org/common/docs/2017_03_09_Rezoluta_nr_011_per_lirimin_e_Ra mush_Haradinaj.pdf

16. Mekaj, G., \& Aliaj, K. (2019). Ethnic Dimension in Kosovo, Security and its Consequences in Transition. ILIRIA International Review, 9(1), 160-177

17. Osmanaj, E. (2018). The (non) consolidation of Kosovo's statehood: The Brussels dialogue ten years after Kosovo's independence. Thesis, 7(1), 45-70.

18. The Dialogue. (n. d.). Association/Community of Serb - Majority Municipalities. Retrieved March 1, 2021, from https://dialogue-info.com/association-community-of-serb-majoritymunicipalities/?fbclid=IwAR3nzq_BKP9t4jGOBhwBxaVZ2RGKx_IwKtU0V9MmO_MJh8wZvySW eLVxcc0

19. The International Crisis Group. (2021, January 25). Relaunching the Kosovo-Serbia Dialogue. Retrieved from https://www.crisisgroup.org/europe-central-asia/balkans/kosovo/262relaunching-kosovo-serbia-dialogue

20. Troncota, M. (2017, February 23). Brussels Based Talks are a "Dialogue of the Deaf". Retrieved from https://kosovotwopointzero.com/en/brussels-based-talks-dialogue-deaf 